\title{
"Does rapid market growth enhance efficiency? An evaluation of the Chinese mutual fund market"
}

\begin{tabular}{|c|c|}
\hline AUTHORS & Carol C. Huang (D https://orcid.org/0000-0002-5477-0073 \\
\hline ARTICLE INFO & $\begin{array}{l}\text { Carol C. Huang (2019). Does rapid market growth enhance efficiency? An } \\
\text { evaluation of the Chinese mutual fund market. Investment Management and } \\
\text { Financial Innovations, 16(2), 383-394. doi:10.21511/imfi.16(2).2019.32 }\end{array}$ \\
\hline DOI & http://dx.doi.org/10.21511/imfi.16(2).2019.32 \\
\hline RELEASED ON & Friday, 05 July 2019 \\
\hline RECEIVED ON & Thursday, 30 May 2019 \\
\hline \multirow[t]{2}{*}{ ACCEPTED ON } & Monday, 01 July 2019 \\
\hline & \begin{tabular}{|l|}
$(\mathrm{oc}) \mathrm{EY}$ \\
\end{tabular} \\
\hline LICENSE & $\begin{array}{l}\text { This work is licensed under a Creative Commons Attribution } 4.0 \text { International } \\
\text { License }\end{array}$ \\
\hline JOURNAL & "Investment Management and Financial Innovations" \\
\hline ISSN PRINT & $1810-4967$ \\
\hline ISSN ONLINE & $1812-9358$ \\
\hline PUBLISHER & LLC "Consulting Publishing Company "Business Perspectives" \\
\hline FOUNDER & LLC "Consulting Publishing Company "Business Perspectives" \\
\hline & 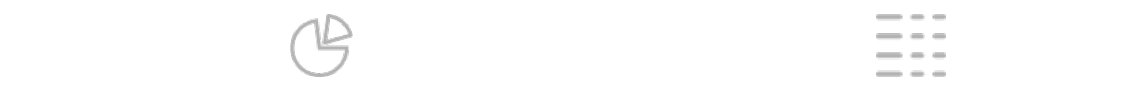 \\
\hline NUMBER OF REFERENCES & NUMBER OF FIGURES \\
\hline 29 & 4 \\
\hline
\end{tabular}

(C) The author(s) 2021. This publication is an open access article. 


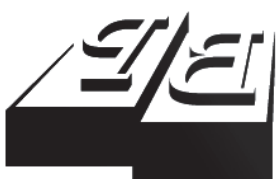

BUSINESS PERSPECTIVES

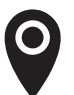

LLC "CPC "Business Perspectives" Hryhorii Skovoroda lane, 10, Sumy, 40022, Ukraine

www.businessperspectives.org

Received on: $30^{\text {th }}$ of May, 2019 Accepted on: $1^{\text {st }}$ of July, 2019

(C) Carol C. Huang, 2019

Carol C. Huang, Ph.D., Associate Professor of Finance, Ancell School of Business, Western Connecticut State University, USA.

\section{DOES RAPID MARKET GROWTH ENHANCE EFFICIENCY? AN EVALUATION OF THE CHINESE MUTUAL FUND MARKET}

\begin{abstract}
In recent years, China's mutual fund market has grown exponentially. With hundreds of new funds introduced into the market each year, an essential question to ask is whether this voluminous growth promotes funds' efficiency, as funds compete for investment. To overcome the drawbacks of traditional portfolio performance metrics, this study utilizes a non-parametric model, data envelopment analysis (DEA), to assess the relative efficiency of equity and hybrid funds for 2016-2018. The empirical results show that despite the development in the fund industry, only a small portion of the funds are fully efficient. While efficiency improvement is observed in equity funds, the efficiency in hybrid funds actually deteriorates. On average, equity funds are more efficient and persistent in performance than hybrid funds. The empirical results also indicate that the primary areas of inefficiency are downside risk management and fund fee structures. For hybrid funds, fund size is also related to efficiency performance. The findings of this study offer implications for how to strengthen the development and stability of the Chinese mutual fund market.
\end{abstract}

Keywords

performance evaluation, Chinese mutual funds, data envelopment analysis, efficiency

JEL Classification C14, G11, G14, G15

\section{INTRODUCTION}

Mutual funds are an important investment vehicle in the financial market. By pooling funds from many investors, mutual funds invest in selected assets in accordance with the objectives of the funds. The benefits that mutual funds offer are professional management and more diversified asset allocations, which investors would not necessarily achieve by purchasing assets themselves. In return for the service received, investors are charged various fees by the mutual funds. While mutual funds are an attractive investment channel, a potential agency problem arises between fund investors who, on the one hand, wish to maximize their portfolio returns, and fund managers who, on the other hand, seek to maximize their compensation, which depends on other metrics. Therefore, assessing the efficiency of mutual fund performance is a vital issue facing investors.

In recent years, the financial market in China has attracted increasing attention, partly due to the country's emerging role in global economic growth and partly due to the gradual opening of its financial market, which offers foreign investors opportunities that were not previously feasible. Like the history of its equity market, the history of China's mutual fund market is comparatively short, with 2018 marking its 20th anniversary. Over the course of these 20 years, the mutual fund 
industry went through several development phases. In the earlier years (1998-2009), the intensive regulation of the industry resulted in sluggish growth in the number and size of the funds (Chaw, 2017). In 2009, the industry was deregulated in an attempt to stimulate the market's development, and in 2012, the Asset Management Association of China (AMAC) was established as a self-regulatory organization subject to the supervision of the China Securities Regulatory Commission (CSRC). In 2013, the revised Securities Investment Fund Law was implemented, reinforcing the legal framework of the industry. Following the explosive growth of the equity market in 2013-2015 and the relaxing of the establishment requirements of the new funds, the Chinese mutual fund industry has witnessed a widespread increase in the number of new funds introduced into the market since 2015.

The objective of this study is to examine whether the rapid growth in the Chinese mutual fund market leads to higher efficiency in funds, as more funds compete for investors. The hypothesis is that for an emerging market such as the Chinese mutual fund market, fast growth in the number of new entrants in the industry may not lead to higher efficiency for pre-existing funds in the market. Instead, the stronger competition could encourage those pre-existing funds to take excessive risks to stay competitive, ultimately deteriorating their efficiency. In this study, the efficiency of Chinese equity and hybrid funds during 2016-2018 is analyzed using data envelopment analysis (DEA), which was introduced by Charnes, Cooper, and Rhodes (1978) and revised by Banker, Charnes, and Cooper (1984). As noted by Murthi, Choi, and Desai (1997), traditional portfolio performance measures, such as Jensen's alpha (Jensen, 1968) and the Sharpe ratio (Sharpe, 1966), not only are sensitive to the choice of benchmarking, but also fail to consider the transaction costs and expenses that investors incur in mutual fund investment. Since the DEA framework is capable of resolving the challenges faced by traditional measures and pointing out potential areas for further improvement, it has become a leading approach for evaluating mutual fund performance (Basso \& Funari, 2016). To further investigate the determinants of inefficiency, a censored Tobit regression proposed by Sueyoshi, Goto, and Omi (2010) is used to provide a thorough analysis.

The remainder of this paper is organized as follows. Section 1 presents the background of the Chinese mutual fund market. Section 2 reviews the literature on the application of DEA models in mutual fund assessment. Section 3 describes the data and the empirical models. Section 4 discusses the empirical findings, and the final section concludes the study.

\section{BACKGROUND OF THE CHINESE MUTUAL FUND MARKET}

Since the establishment of the Shanghai Stock Exchange and the Shenzhen Stock Exchange in the early 1990s, the Chinese capital market has been growing at a very fast pace. As the financial market expanded, the demand for diversified selections of financial instruments prompted the inauguration of China's mutual fund industry, whose first closed-end and open-end funds were introduced in 1998 and 2001, respectively. Similar to its equity market, China's mutual fund market has expanded quickly, from only 107 open-end mutual funds in 2004 to 4,957 at the end of 2018 and from 6 fund management companies in 1998 to 120 at the end of 2018 (The Asset Management Association of China (AMAC) website at http:// www.amac.org.cn/). In the fourth quarter of 2018, China's regulated open-end funds reached a total net asset value of USD 1,768.6 billion (the industry statistics were retrieved from the International Investment Funds Association (IIFA) at https:// www.iifa.ca/index.html, numbers were reported in US dollars, and the funds of funds were excluded), the 8th largest in the world. Figure 1 shows the growth in the number of open-end funds in the Chinese mutual fund industry, and Figure 2 illustrates the increase in total net assets over the years. Clearly, the development of the market has accelerated in recent years.

The Chinese mutual fund industry has some unique features. First, open-end funds play a dom- 


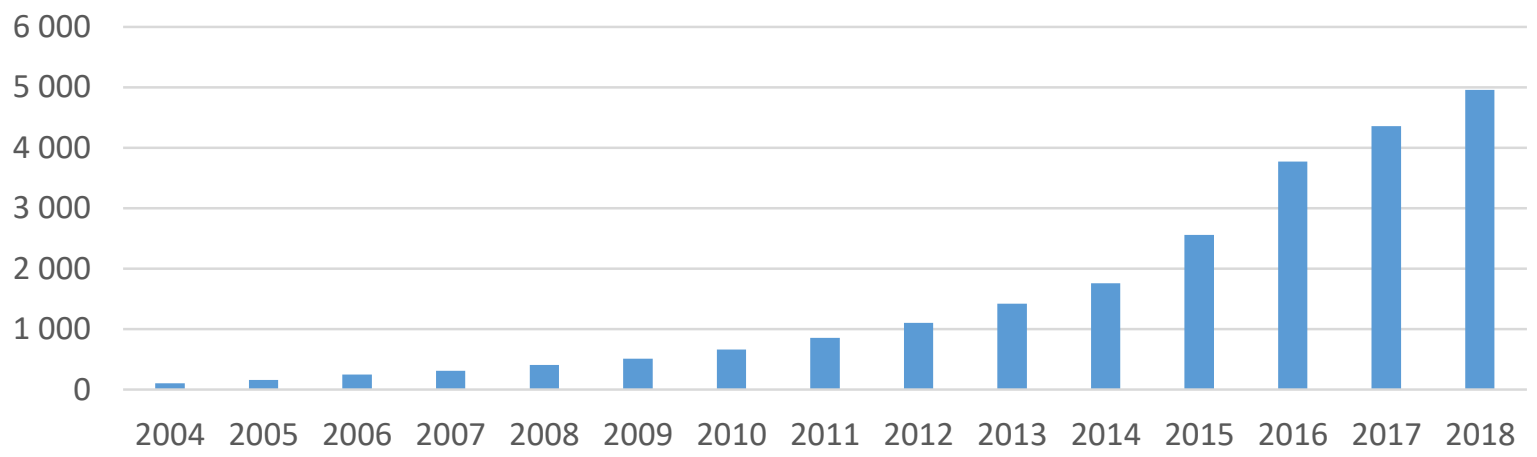

Figure 1. Number of open-end funds in the Chinese mutual fund industry

Source: The International Investment Funds Association (IIFA) at https://www.iifa.ca/index.html

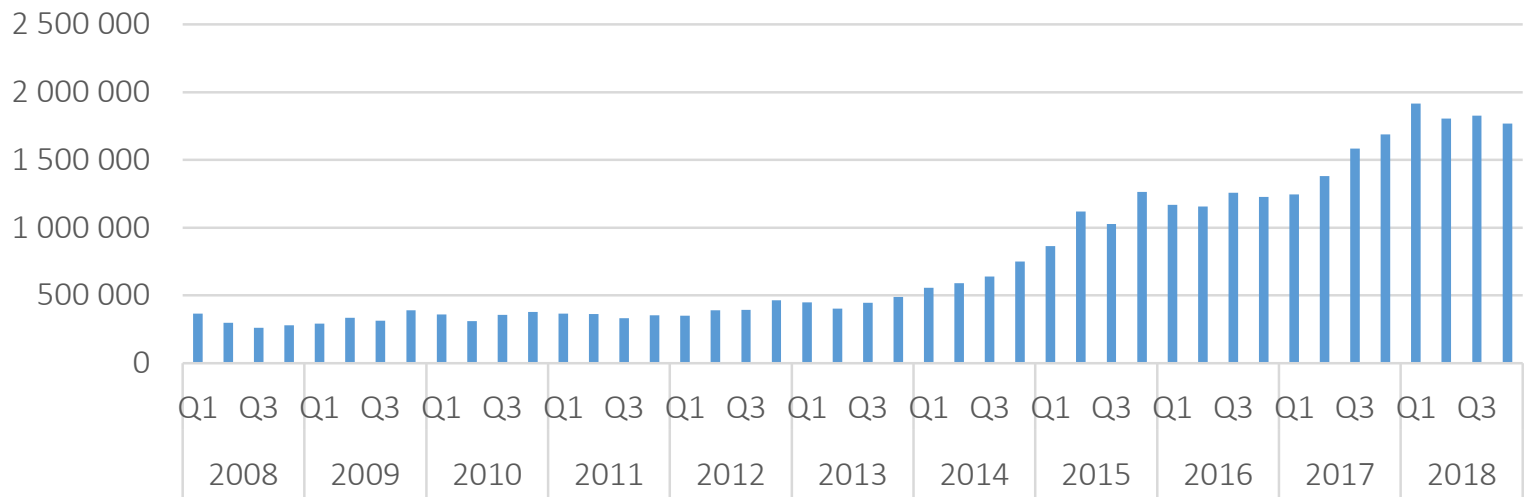

Figure 2. Total net assets (USD million)

inant role in the industry. According to statistics published by the AMAC, at the end of 2018, of the total 5,626 mutual funds in the market, only 669 , or approximately $12 \%$, were closed-end funds, while the net assets of open-end funds represented over $90 \%$ of the industry value. Second, the number of new funds has grown steadily over the years and has rapidly increased since 2015 . For example, in 2017 alone, 975 new funds were introduced into the market (2017 China Securities Investment Fund Fact Book), of which $46.9 \%$ were hybrid funds. While equity funds were initially the major class in the early years of the industry, hybrid funds and bond funds have outnumbered equity funds in recent years, as illustrated in Figure 3. Specifically, since 2015, hybrid funds have represented approximately half of the total number of funds, while equity funds have continued to represent approximately $20 \%$. Third, in terms of the assets under management (AUM) in the industry, since 2014, approximately half have been contributed by money market funds, as shown in Figure 4 .
The dominant role played by money market funds is an important feature of the Chinese mutual fund industry. Although the number of hybrid funds has increased significantly in recent years, the proportion of AUM in the industry attributed to hybrid funds drops from $27 \%$ in 2015 to $11 \%$ in 2018. For equity funds, the share of AUM declines from $9 \%$ in 2015 to $6 \%$ in 2018 . The proportions of asset value represented by different types of funds in the industry reveal the investment and risk preferences of investors. Fourth, most mutual fund accounts are held by individual investors. Over the years, mutual funds have become a popular tool for wealth management in the market. However, as reported in a survey by the AMAC in 2017 , only $38.9 \%$ of investors displayed confidence in mutual fund investment even though over the past 20 years, the average annualized return of equity-oriented funds was $16.5 \%$, approximately $10.5 \%$ higher than the return of the Shanghai Stock Exchange Composite Index. Overall, the Chinese mutual fund industry is still developing. 


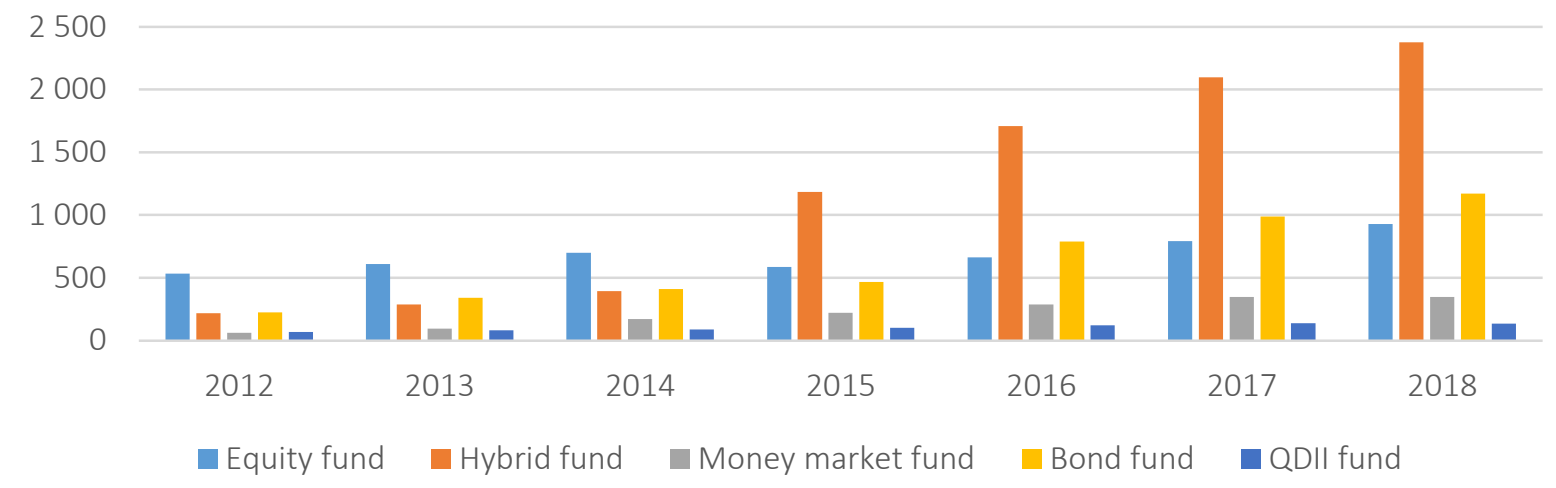

Notes: The data were collected from the Asset Management Association of China at http://www.amac.org.cn/. QDII stands for "qualified domestic institutional investor", a credential that allows the investor to make overseas investments.

Figure 3. Number of open-end funds by type in the Chinese mutual fund industry

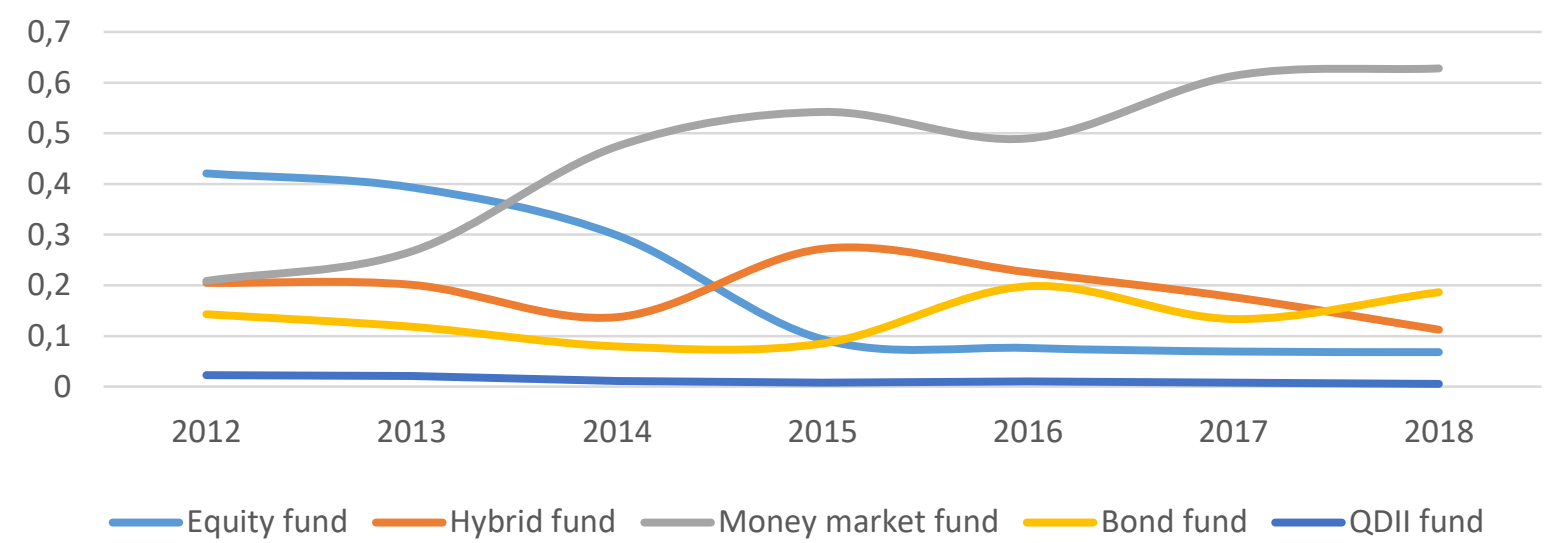

Notes: The data were retrieved from the 2017 China Securities Investment Fund Fact Book and the website of the Asset Management Association of China at http://www.amac.org.cn/. The proportion of the QDII fund was approximately $1 \%$ or less over the years, making it nonsignificant in the chart.

Figure 4. The proportion of assets under management by type in the Chinese mutual fund industry

Investors' investment preferences along with the lack of confidence in the industry warrant the attention of the authorities.

\section{LITERATURE REVIEW}

Murthi, Choi, and Desai (1997) pioneered the integration of the DEA approach into the evaluation of mutual funds and portfolio performance. They argued that the DEA approach resolves the issue of identifying the proper benchmarking, a weakness of the traditional approach, and incorporates transaction costs and fees in the input-output framework. Furthermore, the ability of DEA to rank funds by relative efficiency and to describe inefficient areas helps fund managers identify areas for future improvement.
In studies using DEA to assess mutual fund performance, costs and risks are often denoted as inputs, and returns and performance indices are treated as outputs. For example, Basso and Funari (2001) applied an output-oriented Charnes, Cooper, and Rhodes (CCR; 1978) model to analyze 47 mutual funds in Italy. Their empirical results highlighted the importance of transaction costs in determining the ranking of funds and observed that the DEA approach is suitable for research concerning two conflicting goals, such as return optimization and the pursuit of socially responsible investment. Choi and Murthi (2001) adopted the output-oriented Banker, Charnes, and Cooper (BCC; 1984) and CCR models to analyze the performance of different types of mutual funds. Their empirical results demonstrated that, except for income 
funds, most funds exhibited increasing returns to scale. Additionally, while most funds were able to maintain mean-variance efficiency, they failed to show efficiency in resource allocation.

Galagedera and Silvapulle (2002) investigated the relative efficiency of 257 Australian mutual funds through the use of input-oriented BCC models and various input-output combinations. Their findings revealed that risk-averse funds with high positive net flow assets demonstrated higher overall technical and scale efficiencies. Using the input-oriented BCC model, the results from Sengupta (2003) illustrated that up to $75 \%$ of the US funds studied were mean-variance efficient, and that among the efficient funds, the technology funds presented second-order stochastic dominance over the income and growth funds. Additionally, investors were found to have a preference for skewness. Chen and Lin (2006) demonstrated that incorporating risk measures such as value-at-risk ( $\mathrm{VaR})$ and conditional value-at-risk (CVaR) as inputs into the existing DEA models contributed to a better evaluation of fund performance.

Alexakis and Tsolas (2011) studied equity fund performance in Greece using an input-oriented BCC approach and found that while efficient funds represented a small proportion of the sample examined, the average efficiency increased over time. Chen, Chiu, and Li (2011) examined the performance of balanced and equity funds in Taiwan using system BCC and BCC models in the DEA family. Their results showed that the average efficiency of the balanced funds was higher than that of the equity funds and that categorizing equity and hybrid funds into different groups is important for avoiding estimation errors. Zhao, Wang, and Lai (2011) adopted quadratic-constrained DEA models to analyze mutual fund performance in China and noted that most funds did not exhibit persistence in their efficiency ranking. Moreover, the authors highlighted the significant influence of system risk control on funds' efficiency over time. Babalos, Caporale, and Philippas (2012) evaluated the change in the productivity of Greek equity funds over time using the DEA-based Malmquist index. Their findings revealed that the funds suffered significant efficiency loss during 2003-2009 and that there was a negative relationship between funds' size and the probability of being efficient. Makni, Benouda, and Delhoumi (2015) performed a DEA on Islamic equity funds and observed an overall improvement in the funds from 2002 to 2007. Specifically, the mean efficiency scores during the recession periods were higher than those during the expansion periods, indicating the unique ability of such funds to cope with market turbulence. Gardijan and Krišto (2017) analyzed the relative efficiency of mutual funds in Croatia using the DEA approach and found that the efficiency of the funds varied across pre-crisis, during-crisis, and post-crisis periods and that money market funds were the most efficient type of funds in Croatia.

To further investigate the source of inefficiency in mutual fund performance, in recent years, some studies have adopted a sophisticated version of the DEA framework to conduct fund appraisal. For example, Premachandra, Zhu, Watson, and Galagedera (2012) studied the performance of US mutual fund families using an innovative two-stage DEA model that decomposes overall efficiency into two components: operational management efficiency and portfolio management efficiency. This decomposition allows multiple performance measures, such as risk measures, returns, fees, investment style, and operational and portfolio management skills, to enter the evaluation process at different timings, thus, yielding comprehensive insights regarding the performance of the fund families and identifying which of the two stages plays a determinant role in drawing conclusions of good or bad performance. To allow more flexibility in the output generation process, Galagedera, Watson, Premachandra, and Chen (2016) proposed a two-stage DEA model with leakage variables to assess the performance of US mutual fund families. According to their definition, leakage variables are output variables from the first stage that leave the system without going back to the second stage of the evaluation. Considering the total cash flow to investors (TCF) as the leakage variable, Galagedera et al. (2016) suggest that small fund families are more likely to deliver better performance than large fund families. To gain better insights regarding US equity mutual funds, Galagedera, Roshdi, Fukuyama, and Zhu (2018) 
advanced the two-stage DEA model into a threestage DEA setting, where mutual fund evaluation becomes a procedure consisting of three stages: operational management, resource management, and portfolio management processes. Therefore, not only overall fund performance, but also the efficiency of each of the three stages can be identified to reason the resulting performance.

In summary, while the choices of input and output variables and the modeling in assessing mutual fund performance using the DEA approach are similar, empirical studies have also pointed out that factors that impact the performance of each mutual fund market vary and are unique to the individual markets. While many existing studies have focused on the fund markets in developed economies, studies concerning emerging markets such as the Chinese mutual fund market are still limited due to data availability and the transparency of information disclosure, making the results of this study valuable to those who are interested in exploring the dynamics of the Chinese fund industry.

\section{METHODOLOGIES AND DATA}

\subsection{Data envelopment analysis}

Data envelopment analysis (DEA), proposed by Charnes, Cooper, and Rhodes (1978), is a linear data-driven optimization process for evaluating the efficiency of a group of peer entities called decision making units (DMUs), which have common inputs and outputs. DEA constructs a non-parametric piecewise efficient frontier based on the efficient DMUs in the reference group and measures the relative efficiency of each DMU according to its distance from the frontier. The efficiency score of each DMU is between zero and one, with one representing efficient (on the efficient frontier) and less than one inefficient. In fact, the DEA process calibrates a DMU's ability to convert multiple inputs into outputs. In the DEA framework, there are two forms of representations: input-oriented and output-oriented. The input-oriented measure focuses on reaching DEA efficiency by proportionally reducing the inputs while maintaining the same desired output levels. The output-oriented measure seeks to obtain DEA efficiency by expanding the level of outputs while keeping the same level of inputs (Alexakis \& Tsolas, 2011). As mentioned by Banker and Morey (1986), Charnes et al. (1984), and Cooper, Seiford, and Zhu (2011), there are many advantages of using DEA in evaluating efficiency. First, DEA is a non-parametric model that does not require assumptions of functional forms or benchmarking, as required in traditional parametric models. DEA focuses on optimizing each individual DMU instead of searching for the average among the observations. Second, because it uses a linear programming process, DEA is capable of taking on multiple inputs and outputs simultaneously to produce a single efficiency score that summarizes the relative efficiency of each DMU and offers a possible pathway for future improvement. Third, the DEA model has the property of unit invariance, which offers flexibility in empirical computations.

Define $j=1, \ldots, n$ as the number of $D M U_{j}$, $r=1, \ldots, l$ as the number of outputs, and $i=1, \ldots, m$ as the number of inputs. $y_{r j}$ is the output level of $D M U_{j}$, and $x_{i j}$ is the input level of $D M U_{j}$. Following Charnes, Cooper, and Rhodes (1978), Charnes et al. (1984), and Cooper, Seiford, and Zhu (2011), the dual form of the CCR model that calibrates the relative efficiency score $\theta_{o}$ for $D M U_{o}$, the $D M U$ under evaluation, can be presented as follows:

$$
\begin{aligned}
& \min \theta_{o}-\varepsilon\left(\sum_{i=1}^{m} s_{i}^{-}+\sum_{r=1}^{l} s_{r}^{+}\right), \\
\text {s.t. } & \sum_{j=1}^{n} \lambda_{j} x_{i j}+s_{i}^{-}=\theta_{o} x_{i o}, i=1, \ldots, m, \\
& \sum_{j=1}^{n} \lambda_{j} y_{r j}-s_{r}^{+}=y_{r o}, \quad r=1, \ldots, l, \\
& s_{i}^{-}, \lambda_{j}, s_{r}^{+} \geq 0, \forall i, j, r,
\end{aligned}
$$

where $\lambda_{j}$ is the intensity variables illustrating linear combinations of $D M U_{j}, \varepsilon$ is a non-Archimedean small number, and $s_{i}^{-}$and $s_{r}^{+}$are slack variables. Equation (1) is the input-oriented CCR model, which assumes constant returns to scale. Banker, Charnes, and Cooper (1984) extended the above CCR model by adding $\sum_{j=1}^{n} \lambda_{i}=1(\lambda \geq 0)$ to 
allow for variable returns to scale, building the input-oriented BCC model with the following representation:

$$
\begin{aligned}
& \min \theta_{o}-\varepsilon\left(\sum_{i=1}^{m} s_{i}^{-}+\sum_{r=1}^{l} s_{r}^{+}\right), \\
\text {s.t. } & \sum_{j=1}^{n} \lambda_{j} x_{i j}+s_{i}^{-}=\theta_{o} x_{i o}, i=1, \ldots, m, \\
& \sum_{j=1}^{n} \lambda_{j} y_{r j}-s_{r}^{+}=y_{r o}, r=1, \ldots, l, \\
& \sum_{j=1}^{n} \lambda_{i}=1, \\
& s_{i}^{-}, \lambda_{j}, s_{r}^{+} \geq 0, \forall i, j, r .
\end{aligned}
$$

In the context of mutual fund appraisal, each fund is denoted as DMU. Since the empirical results from DEA are sensitive to the choices of inputs and outputs defined in the model, the common practice is to select the variables based on theory. According to Tokic (2012), the selection of inputs and outputs in the DEA framework typically follows the concepts illustrated in Markowitz's risk-return model, and the input-oriented DEA with variable returns to scale is generally chosen to rank competing funds. Therefore, common input choices may include various risk variables, costs, and specific attributes that may contribute to fund performance, while the outputs usually contain variables related to returns or indices for portfolio performance. Following the convention, in the present paper, a BCC input-oriented DEA model was adopted to assess fund performance. The input-oriented version of DEA was chosen, because the levels of fees and the riskiness of investments are manageable, making resource conservation feasible for fund managers, while the returns of the funds are sometimes subject to a greater complexity that may not always be under managers' control. The inputs included are (1) variables that describe costs: the subscription fee, redemption fee, and expense ratio; and (2) variables that calibrate the riskiness of investments: the annualized standard deviation of the return and the 1-year CVaR at the 95\% confidence level. CVaR, introduced by Rockafellar and Uryasev (2000), is a measure of downside risk that is calculated by the weighted average of the worst-case scenarios at a specified confidence interval during the predefined period. As suggested in Chen and Lin (2006), combining a CVaR with other conventional risk measures can lead to a better assessment of fund performance. Thus, the standard deviation and $\mathrm{CVaR}$ are the risk measures considered in this study to provide a thorough investigation of the impacts of volatility and downside risk on a fund's efficiency. The output of the study is the 1-year fund return.

\subsection{The impact of fund size}

To investigate whether the size of a fund plays a role in determining its efficiency, this study adopts the censored Tobit regression suggested by Sueyoshi, Goto, and Omi (2010) to analyze its impact. There are two steps involved in this process. First, the efficiency score obtained in the DEA model is transformed by denoting the corresponding inefficiency of a given fund as "INEFF $=(1 / D E A$ efficiency score) -1 ". Such a transformation is necessary, because it relaxes the boundaries of the original DEA efficiency score from $[0,1]$ to $[0, \infty]$, which sets the ground for the Tobit regression. Second, a Tobit regression is performed to investigate how fund size contributes to the inefficiency of the funds. The regression can be presented as follows:

$$
\begin{aligned}
& I N E F F_{j}=X_{j}^{\prime} \beta+u_{j}, j=1, \ldots, n, \\
& I N E F F_{j}=\left\{\begin{array}{ccc}
I N E F F_{j} & \text { if } & I N E F F_{j}>0 \\
0 & \text { if } & I_{N E F F_{j}} \leq 0
\end{array}\right.
\end{aligned}
$$

where $X_{j}$ is the vector of the explanatory variables such as fund size, costs, and risk measures, $\beta$ is the vector of the coefficients, and $u_{j}$ is a normally and independently distributed error term with constant variance and zero mean. Therefore, a zero in the inefficiency score $I N E F F_{j}$ indicates full efficiency.

\subsection{Data}

The data studied are Chinese domestic open-end equity and hybrid funds. The period investigated spans from 2016 to 2018, a period during which the fund market was rapidly expanding. Since the objective of this study is to investigate whether the efficiency of existing funds is improved as a 
Table 1. Descriptive statistics of Chinese equity and hybrid funds for 2016-2018

\begin{tabular}{|c|c|c|c|c|}
\hline Variable & Mean & Std. Dev. & Min & Max \\
\hline \multicolumn{5}{|c|}{ Panel A. Equity funds } \\
\hline Age $(y r)$ & 3.3988 & 2.0438 & 1.0000 & 14.6306 \\
\hline Subscription fee (\%) & 1.4370 & 0.2715 & 0.0000 & 1.8000 \\
\hline Redemption fee (\%) & 1.3055 & 0.4146 & 0.0000 & 1.5000 \\
\hline Expense (\%) & 1.7116 & 0.2143 & 0.6000 & 3.0000 \\
\hline TA (mil) & $1,098.3365$ & $1,493.9650$ & 5.5280 & $13,670.7190$ \\
\hline Standard deviation & 21.5917 & 6.4838 & 8.7251 & 46.5300 \\
\hline CVaR & 3.4644 & 1.3889 & 1.0804 & 7.3465 \\
\hline $1 Y r$ return $(\%)$ & -7.1051 & 21.1519 & -47.9459 & 64.9682 \\
\hline Sharpe ratio (\%) & -0.1561 & 1.1884 & -1.9091 & 3.8478 \\
\hline \multicolumn{5}{|c|}{ Panel B. Hybrid funds } \\
\hline Age $(y r)$ & 5.6184 & 3.7961 & 1.0056 & 17.2694 \\
\hline Subscription fee (\%) & 1.2654 & 0.4740 & 0.0000 & 2.0000 \\
\hline Redemption fee (\%) & 0.9493 & 0.5470 & 0.0000 & 2.0000 \\
\hline Expense (\%) & 1.5186 & 0.3884 & 0.1500 & 4.0000 \\
\hline TA (mil) & 879.3652 & $1,332.3808$ & 0.0010 & $15,124.3540$ \\
\hline Standard deviation & 15.6272 & 10.5397 & 0.4283 & 219.5716 \\
\hline CVaR & 2.4398 & 1.7027 & 0.0217 & 7.9052 \\
\hline $1 Y r$ return $(\%)$ & -4.6771 & 17.8678 & -44.2848 & 122.6366 \\
\hline Sharpe ratio (\%) & 0.0754 & 1.3314 & -2.8261 & 8.9980 \\
\hline \multicolumn{5}{|c|}{ Panel C. Market returns } \\
\hline CSI 300 (\%) & -4.9388 & 24.1747 & -25.3098 & 21.7750 \\
\hline
\end{tabular}

Note: CSI 300 is a market index consisting of 300 largest stocks traded in the Shanghai and Shenzhen Stock Exchanges. Total assets (TAs) are reported in millions of Chinese yuan, and the CVaRs are presented as absolute values.

result of the rapid growth in the number of new funds offered on the market, for a fund to be included in the sample, it needs to have been established and to have had its first net asset value (NAV) available before the end of 2015 to ensure that the fund has its annual return data available for analysis starting in 2016. For equity funds, only those maintaining an equity ratio of at least $60 \%$ are considered. Funds with missing data are excluded. To minimize the possibility of survivorship bias, funds that meet the criteria specified above are included even if they ceased operation after the sample period. In total, as of the end of 2016, 1,317 funds meet the criteria, of which 146 are equity funds and 1,171 are hybrid funds. These same 1,317 funds are analyzed for three consecutive years to observe the improvement or deterioration in relative efficiency over time. The funds' data were retrieved from the Taiwan Economic Journal, a financial data provider specializing in emerging Asian markets.

Table 1 provides the descriptive statistics of the funds investigated. The Chinese equity market performed poorly in 2016 and 2018. As a result, the average returns for equity and hybrid funds were negatively impacted, and the 2016-2018 period ended with an average annual return of $-7.10 \%$ for equity funds and $-4.67 \%$ for hybrid funds. According to Table 1, the average ages are 3.39 years for equity funds and 5.61 years for hybrid funds. In general, equity funds have larger average total assets, higher transaction costs in terms of subscription and redemption fees, a higher expense ratio, and higher riskiness, as captured by the standard deviation and CVaR of the return, than hybrid funds. Thus, equity funds will not only see higher volatility in the return, but also anticipate a greater expected loss.

\section{EMPIRICAL RESULTS}

\subsection{Results}

Table 2 reports the summary results of the relative efficiency of the funds studied. The average efficiency score for equity funds rose from 0.6882 in 2016 to 0.8307 in 2018, indicating improvement in overall efficiency despite the fluctuations in the Chinese equity market in 2018. The number of efficient funds increased from 8 in 2016 
Table 2. Summary of the efficiency scores of equity and hybrid funds

\begin{tabular}{|c|c|c|c|c|c|c|c|}
\hline \multicolumn{4}{|c|}{ Panel A. Equity funds } & \multicolumn{4}{|c|}{ Panel B. Hybrid funds } \\
\hline Efficiency Score & 2016 & 2017 & 2018 & Efficiency Score & 2016 & 2017 & 2018 \\
\hline Mean & 0.6882 & 0.7714 & 0.8307 & Mean & 0.4038 & 0.4746 & 0.3517 \\
\hline Median & 0.6468 & 0.7597 & 0.8374 & Median & 0.3037 & 0.4240 & 0.3080 \\
\hline Standard deviation & 0.1115 & 0.1164 & 0.0880 & Standard deviation & 0.2176 & 0.2019 & 0.1562 \\
\hline Q1 & 0.6136 & 0.6850 & 0.7726 & Q1 & 0.2969 & 0.3073 & 0.2512 \\
\hline Q3 & 0.7156 & 0.8362 & 0.8885 & Q3 & 0.5117 & 0.6073 & 0.3599 \\
\hline Number of efficient funds & 8 & 10 & 10 & Number of efficient funds & 27 & 22 & 15 \\
\hline$\%$ of efficient funds & $5.48 \%$ & $6.85 \%$ & $6.85 \%$ & $\%$ of efficient funds & $2.31 \%$ & $1.88 \%$ & $1.28 \%$ \\
\hline
\end{tabular}

Note: Q1 and Q3 refer to the first and third quartiles, respectively.

Table 3. Summary of funds' persistent efficiency

\begin{tabular}{|c|c|c|}
\hline & 2016-2017 & 2017-2018 \\
\hline \multicolumn{3}{|c|}{ Panel A. Equity funds } \\
\hline Number of persistent funds & 123 & 107 \\
\hline$\%$ of persistent funds & $84.24 \%$ & $73.28 \%$ \\
\hline \multicolumn{3}{|c|}{ Panel B. Hybrid funds } \\
\hline Number of persistent funds & 910 & 293 \\
\hline$\%$ of persistent funds & $77.71 \%$ & $25.02 \%$ \\
\hline
\end{tabular}

Note: A fund's persistence is defined as receiving an efficiency score at or above the score obtained the year before.

to 10 in both 2017 and 2018. Although the percentages of equity funds characterized as DEAefficient were low, i.e. only approximately $5.48 \%$ in 2016 and $6.85 \%$ in 2017 and 2018, the majority of funds approached higher efficiencies over the period. Regarding hybrid funds, the average efficiency score decreased from 0.4038 in 2016 to 0.3517 in 2018, indicating a deterioration in overall efficiency. The percentage of DEA-efficient funds dropped from $2.31 \%$ in 2016 to $1.28 \%$ in 2018. During 2016-2018, most hybrid funds were not DEA-efficient.

Table 3 describes the persistent efficiency of funds over the sample period. A fund's persistence is defined as receiving an efficiency score at or above the score obtained the year before. The empirical results illustrate that during 2016-2017, when the market was performing well, the majority of funds demonstrated persistent efficiency, with $84.24 \%$ of equity funds and $77.71 \%$ of hybrid funds exhibiting persistence. While $73.28 \%$ of equity funds were able to maintain persistence when the market declined in 2017-2018, in the case of hybrid funds, the number of persistent funds dropped significantly, with only $25.02 \%$ of hybrid funds demonstrating efficiency improvement. Hybrid funds' persistence, therefore, was sensitive to market conditions.
In summary, only a small portion of equity and hybrid funds obtained perfect DEA efficiency during the period analyzed. The rapid expansion of China's mutual fund market in 2016-2018 did not lead to a significant improvement in the number of perfectly efficient funds among the pre-existing funds. Such a high inefficiency rate explains why only approximately $38.9 \%$ of fund investors expressed confidence in mutual fund investing, as discussed in the earlier section. As the authorities continue to encourage the establishment of new funds to serve various investment objectives, including retirement savings, how to obtain a balance between the quantity and quality of funds that best sustains the healthy growth of the industry is a question that the authorities need to address.

\subsection{Slack analysis}

One of the advantages of adopting the DEA model is that, for each DMU, the model not only produces an efficiency score, but also illustrates the areas of inefficiency by means of the slack value for each input variable. According to the definition in DEA, slack variables, refer to the difference between the projected target input and output values and the DMU's current values (Babalos et al., 2012). Since a DMU is said to be $100 \%$ efficient if 
Table 4. Mean slacks in the inputs for Chinese equity and hybrid funds

\begin{tabular}{l|l|l|l|l|l|l|l}
\hline \multicolumn{7}{c}{ Panel A. Absolute slacks } \\
\hline Equity funds & $\mathbf{2 0 1 6}$ & $\mathbf{2 0 1 7}$ & $\mathbf{2 0 1 8}$ & Hybrid funds & $\mathbf{2 0 1 6}$ & $\mathbf{2 0 1 7}$ & $\mathbf{2 0 1 8}$ \\
\hline Subscription & 0.0362 & 0.0229 & 0.0347 & Subscription & 0.1629 & 0.2418 & 0.1230 \\
Redemption & 0.4280 & 0.3876 & 0.3252 & Redemption & 0.0037 & 0.0626 & 0.0147 \\
Expense & 0.0000 & 0.0001 & 0.0159 & Expense & 0.0033 & 0.0108 & 0.0001 \\
Std. Dev. & 0.0324 & 0.0175 & 0.3864 & Std. Dev. & 0.0925 & 0.0156 & 0.0804 \\
\hline CVaR & 0.2593 & 0.1584 & 0.0234 & CVaR & 0.1122 & 0.0764 & 0.0596 \\
\hline & & & Panel B. Relative slacks & & & \\
\hline Equity funds & $\mathbf{2 0 1 6}$ & $\mathbf{2 0 1 7}$ & $\mathbf{2 0 1 8}$ & Hybrid funds & $\mathbf{2 0 1 6}$ & $\mathbf{2 0 1 7}$ & $\mathbf{2 0 1 8}$ \\
\hline Subscription & 0.0252 & 0.0159 & 0.0242 & Subscription & 0.1287 & 0.1911 & 0.0972 \\
Redemption & 0.3278 & 0.2969 & 0.2491 & Redemption & 0.0039 & 0.0659 & 0.0155 \\
\hline Expense & 0.0000 & 0.0001 & 0.0093 & Expense & 0.0022 & 0.0071 & 0.0000 \\
Std. Dev. & 0.0012 & 0.0012 & 0.0164 & Std. Dev. & 0.0049 & 0.0015 & 0.0046 \\
CVaR & 0.0517 & 0.0799 & 0.0069 & CVaR & 0.0335 & 0.0521 & 0.0238 \\
\hline
\end{tabular}

and only if $\theta^{*}=1$ and all slacks are zero (Cooper et al., 2011), by observing the slacks, we are able to evaluate the priority and size of improvement necessary to make an inefficient DMU reach the efficient frontier. Following the methodology proposed by Murthi, Choi, and Desai (1997), the slack analysis is presented in Table 4, where Panel A reports the absolute mean slacks and Panel B provides the relative mean slacks, calculated as the absolute mean slack of an input divided by the mean of the input.

According to Table 4, equity funds have a large relative slack in redemption fees, and regarding hybrid funds, the subscription fee is the major area for improvement to progress toward the efficient frontier. Since both subscription and redemption fees are transaction costs, the empirical results suggest the need to revisit the fee structure for both types of funds to achieve higher efficiency. Additionally, given that both types of funds have very little mean absolute slacks in the expense ratio, the empirical results reveal that the current expense ratio levels are well utilized.
Notably, the absolute slacks for the risk measures of equity and hybrid funds, as captured by the standard deviation and CVaR, are nonzero, indicating that these mutual funds are not mean-variance efficient. Specifically, downside risk management warrants special attention, because the relative mean slacks for the CVaR are the second largest slack for both types of funds. This result provides support for the hypothesis that excessive risk-taking is partly responsible for the funds' inefficiency during the period studied.

\subsection{The size of the fund}

Table 5 reports the results of the censored Tobit regression. The empirical results confirm the findings in the previous slack analysis, i.e., that the downside risk and the fees are positively correlated to the inefficiency of equity and hybrid funds. Regarding the impact of fund size, the results indicate that for hybrid funds, fund size and the inefficiency score are negatively related, highlighting the importance of obtaining the scale effect for hybrid funds. This result is consistent with the ar-

Table 5. Results from the censored Tobit regression

\begin{tabular}{|c|c|c|c|c|c|c|c|}
\hline \multicolumn{4}{|c|}{ Equity funds } & \multicolumn{4}{|c|}{ Hybrid funds } \\
\hline Variable & Coefficient & Std. error & $p$-value & Variable & Coefficient & Std. error & $p$-value \\
\hline Constant & $-0.6468^{*}$ & 0.0803 & 0.0000 & Constant & $-1.1578^{*}$ & 0.0506 & 0.0000 \\
\hline Size & 0.0081 & 0.0055 & 0.1404 & Size & $-0.0800^{*}$ & 0.0053 & 0.0000 \\
\hline CVaR & $0.1633^{*}$ & 0.0167 & 0.0000 & CVaR & $0.2878^{*}$ & 0.0132 & 0.0000 \\
\hline Std. Dev. & -0.0162 & 0.0036 & 0.0513 & Std. Dev. & 0.0021 & 0.0021 & 0.3226 \\
\hline Expense & $0.2653 *$ & 0.0425 & 0.0000 & Expense & $1.1281^{*}$ & 0.0346 & 0.0000 \\
\hline Transaction costs & $0.0955^{*}$ & 0.0144 & 0.0000 & Transaction costs & $0.4793^{*}$ & 0.0145 & 0.0000 \\
\hline
\end{tabular}

Notes: The dependent variable in this regression is the inefficiency score described in Section 3.2 . The size variable is the logarithm of funds' total assets. Transaction costs are the combination of subscription and redemption fees. $*$ indicates significance at the $1 \%$ level. 
gument in Li and Lin (2011) that in the Chinese fund market, large funds outperform small and medium-sized funds. During the sample period, hybrid funds saw a $40 \%$ increase in the number of funds, but a deterioration in their average efficien- cy. Therefore, identifying ways to expand the size of individual hybrid funds is important for fund managers who seek to enhance their funds' efficiency. On the other hand, the influence of fund size on equity funds' efficiency is nonsignificant.

\section{CONCLUSION}

In recent years, the Chinese mutual fund market has expanded at a tremendous pace. Investors' desire to seek more investment opportunities coupled with the relaxing of regulations for fund establishment has led to hundreds of new funds offered on the market each year. Facing a manifold number of funds, investors need to know whether the fast expansion in the number of new funds offered on the fund market leads to an improvement in funds' efficiency.

Due to the difficulties in mutual fund appraisal that traditional methods encounter, this study adopts an alternative non-parametric input-oriented DEA model to investigate the efficiency of funds. The empirical results show that during the period investigated, only a small portion of equity and hybrid funds were DEA-efficient. The rapid growth in the fund market did not lead to a significant increase in the number of perfectly efficient funds. On average, equity funds were more efficient and persistent in performance than hybrid funds. Fund size also contributes to the efficiency performance of hybrid funds. However, neither type of fund is mean-variance efficient, as illustrated in the slack analysis. While the consensus is that competition may bring higher efficiency, in the case of this study, higher competition may instead encourage fund managers to take excessive risks and, consequently, make funds less efficient. Excessive risk-taking, as measured by CVaR, and fee structures are the primary areas for improvement to enhance funds' efficiency in order to sustain the long-term growth of the industry and win over investors' confidence in future investing.

\section{REFERENCES}

1. Alexakis, P., \& Tsolas, I. (2011). Appraisal of mutual equity fund performance using data envelopment analysis. Multinational Finance Journal, 15(3/4), 273-296. Retrieved from https://papers.ssrn.com/sol3/papers.cfm?abstract_id=2622929

2. Babalos, V., Caporale, G. M., \& Philippas, N. (2012). Efficiency evaluation of Greek equity funds. Research in International Business and Finance, 26(2), 317 333. https://doi.org/10.1016/j. ribaf.2012.01.003

3. Banker, R. D., \& Morey, R. (1986). The use of categorical variables in data envelopment analysis. Management Science, 32(12), 1613-1627. Retrieved from https://www.jstor.org/ stable/2631835?seq=1\#page_scan_ tab_contents
4. Banker, R. D., Charnes, A., \& Cooper, W. W. (1984). Some models for estimating technical and scale inefficiencies in data envelopment analysis. Management Science, 30(9), 10781092. https://doi.org/10.1287/ mnsc.30.9.1078

5. Basso, A. \& Funari, S. (2016). DEA performance assessment of mutual funds. In J. Zhu (Ed.), Data Envelopment Analysis: A handbook of empirical studies and applications. Springer, New York.

6. Basso, A., \& Funari, S. (2001). A data envelopment analysis approach to measure the mutual fund performance. European Journal of Operational Research, 135(3), 477-492. https://doi.org/10.1016/S03772217(00)00311-8

7. Charnes, A., Cooper, W. W., \& Rhodes, E. (1978). Measuring the efficiency of decision making units. European Journal of Operational Research, 2(6), 429-444. https://doi. org/10.1016/0377-2217(78)90138-8

8. Charnes, A., Cooper, W. W., Lewin, A. Y., Morey, R. C., \& Rousseau, J. (1984). Sensitivity and stability analysis in DEA. Annals of Operations Research, 2(1), 139-156. Retrieved from https://link.springer.com/ article/10.1007\%2FBF01874736

9. Chaw, C. (2017). China Mutual Funds 2017. China Knowledge Press Pte Ltd.

10. Chen, Y. C., Chiu, Y. H., \& Li, M. C. (2011). Mutual fund performance evaluation - Application of system BCC model. South African Journal of Economics, 79(1), 1-16. http://dx.doi.org/10.1111/j.18136982.2011.01263.x 
11. Chen, Z., \& Lin, R. (2006). Mutual fund performance evaluation using data envelopment analysis with new risk measures. $O R$ Spectrum, 28(3), 375-398. Retrieved from https://link. springer.com/article/10.1007/ s00291-005-0032-1

12. Choi, Y., \& Murthi, B. (2001). Relative performance evaluation of mutual funds: A nonparametric approach. Journal of Business Finance \& Accounting 28(7-8), 853-876. https://doi. org/10.1111/1468-5957.00396

13. Cooper, W. W., Seiford, L., \& Zhu, J. (Eds.) (2011). Handbook on Data Envelopment Analysis. Springer, New York

14. Galagedera, D. U. A., \& Silvapulle, P. (2002). Australian mutual fund performance appraisal using data envelopment analysis. Managerial Finance, 28(9), 60-73. https://doi. org/10.1108/03074350210768077

15. Galagedera, D. U. A., Roshdi, I., Fukuyama, H., \& Zhu, J. (2018). A new network DEA model for mutual fund performance appraisal: An application to U.S. equity mutual funds. Omega, 77, 168-179. https://doi.org/10.1016/j. omega.2017.06.006

16. Galagedera, D. U. A., Watson, J., Premachandra, I. M., \& Chen, Y. (2016). Modeling leakage in twostage DEA models: An application to US mutual fund families. Omega, 61, 62-77. https://doi. org/10.1016/j.omega.2015.07.007

17. Gardijan, M., \& Krišto, J. (2017). Efficiency of mutual funds in Croatia: A DEA-based approach applied in the pre-crisis, crisis and post crisis period. Croatian
Operational Research Review, 8(1), 77-92. https://doi.org/10.17535/ crorr.2017.0005

18. Jensen, M. (1968). The performance of mutual funds in the period 1945-1964. Journal of Finance, 23(2), 389-416. Retrieved from https://papers.ssrn.com/sol3/ papers.cfm?abstract_id $=244153$

19. Li, N., \& Lin, C. (2011). Understanding emerging market equity mutual funds: The case of China. Financial Services Review, 20(1), 1-19. Retrieved from https://www.questia.com/ library/journal/1P3-2416817301/ understanding-emerging-marketequity-mutual-funds

20. Makni, R., Benouda, O., \& Delhoumi, E. (2015). Large scale analysis of Islamic equity funds using a meta-frontier approach with data envelopment analysis. Research in International Business and Finance, 34, 324337. https://doi.org/10.1016/j. ribaf.2015.02.014

21. Murthi, B. P. S., Choi, Y. K., \& Desai, P. (1997). Efficiency of mutual funds and portfolio performance measurement: A non-parametric approach. European Journal of Operational Research, 98(2), 408-418. https://doi.org/10.1016/S03772217(96)00356-6

22. Premachandra, I. M., Zhu, J., Watson, J., \& Galagedera, D. U. A. (2012). Best-performing US mutual fund families from 1993 to 2008: Evidence from a novel twostage DEA model for efficiency decomposition. Journal of Banking and Finance, 36(12), 3302-3317. https://doi.org/10.1016/j.jbankfin.2012.07.018
23. Rockafellar, R. T., \& Uryasev, S. (2000). Optimization of conditional value-at-risk. Journal of Risk, 2, 21-41. https://doi. org/10.21314/JOR.2000.038

24. Sengupta, J. (2003). Efficiency tests for mutual fund portfolios. Applied Financial Economics, 13(12), 869-876. https://doi. org/10.1080/09603100210161992

25. Sharpe, W. (1966). Mutual fund performance. The Journal of Business, 39(1), 119-138. Retrieved from https://www.jstor. org/stable/2351741?seq=1\#page_ scan_tab_contents

26. Sueyoshi, T., Goto, M., \& Omi, Y. (2010). Corporate governance and firm performance: Evidence from Japanese manufacturing industries after the lost decade. European Journal of Operational Research, 203(3), 724-736. https://doi.org/10.1016/j. ejor.2009.09.021

27. The Asset Management Association of China (2018). 2017 China Securities Investment Fund Fact Book. China Financial \& Economic Publishing House.

28. Tokic, D. (2012). Managed futures for long-term investors: A DEA ranking analysis. Australian Economic Review, 45(4), 422-440. http://dx.doi.org/10.1111/j.14678462.2012.00699.x

29. Zhao, X., Wang, S., \& Lai, K. K. (2011). Mutual funds performance evaluation based on endogenous benchmarks. Expert Systems with Applications, 38(4), 3663-3670. https://doi. org/10.1016/j.eswa.2010.09.022 